\title{
CHARACTERISTICS OF COTTON FABRICS PRODUCED FROM SIROSPUN AND PLIED YARNS
}

\author{
EL-SAYED, M. A. M. AND SUZAN H. SANAD
}

Cotton Research Institute, ARC, Giza

(Manuscript received 23 February 2011)

\begin{abstract}
The use of sirospun yarns eliminates two processing stages in comparison with the two-fold yarns production process and consequently, reduces the cost of production. It is claimed that, it brings many advantages for yarn and fabric quality. However, the benefit of this new concept is still to be investigated extensively.

The aim of this paper is to present and analyse the quality parameters of the (sirospun yarns and conventional two-fold yarns and fabrics) of counts $50 / 2$ and $80 / 2$. In addition, the yarn properties of single yarn counts $25 / 1$ and $40 / 1$.

Giza 88 Egyptian cotton combed at $18 \%$ noils was used. Yarn physical properties including tensile strength, elongation, unevenness and hairiness were measured and compared. The sirospun yarn values achieved were superb, with regard to yarn strength, elongation and hairiness. The results indicated that increasing the yarn count within the range of $\mathrm{Ne} \mathrm{50/2} \mathrm{to} \mathrm{Ne} \mathrm{80/2}$ decreased the hairiness of sirospun yarn. It is also shown that the hairiness of sirospun yarns is significantly less than that of two-fold ring spun yarns. According to results, the structural differences between sirospun and conventional two-fold yarns had a significant influence on weft direction fabric properties. Weft direction woven from sirospun yarns were found to have higher tensile strength than fabrics woven from ring two-fold yarns.

The test results regarding color reflectance and color strength $(\mathrm{K} / \mathrm{S})$ indicated that there is insignificant difference in color reflectance between the fabrics of sirospun and conventional twofold yarns in 80/2 and 50/2 Ne. The sirospun fabrics recorded slightly lower color strength than the conventional two-fold yarn fabrics. This result reveals that much less dye can be used for the fabrics of sirospun fabric, so their dyeing cost might be lower for the same depth of shade in comparison to fabrics of conventional two-fold yarns.
\end{abstract}

\section{INTRODUCTION}

In ring spinning system, the value addition can be obtained by producing a yarn with novel structures that can be directly taken to the weaving or to produce fancy effects in the fabrics.

Single yarns are generally plied by the conventional method having two stage processes. In conventional plying, the first stage is to assemble two or more single yarns which are wound onto the bobbin and then to twist the assembly around each other with plying/folding and two-for-one processes. Therefore, plying and two-for- 
one can be defined as an expensive process due to the need of the additional twisting as illustrated in Figure1. In siro spinning method, two similar or different roving strands are fed into the drafting system and maintained separately throughout the drafting process till the nip of the front roller, using suitable guides. At the delivery roller nip, both strands are condensed together, twisted and wound by the spindle in conventional method. The initial steps of Siro spinning technology were taken at CSIRO (Commonwealth Scientific \& Industrial Research Organization) in the mid1970s (Anonymous 1993), Cheng and Sun (1993), Sun and Cheng (2000). Convergence of strands at the delivery roller is governed by spinning speed, strand twists and fineness of the yarn; optimal convergence angle of the two strands in equilibrium is $90^{\circ}$ with resonance at $127^{\circ}$. Strand spacing has a pronounced influence on packing density, yarn unevenness, hairiness, elongation and end breakage during spinning process (Saravanan and Kumar 2009).

Yilmaz and Ibrahim (2010) reported that regarding the yarn properties, Siro spinning process is especially better with regard to its tensile properties while conventional plying process attracts attention with mainly lower yarn hairiness and also other yarn properties. Concerning the differences in single and Siro-spun yarn properties, the yarn hairiness was found to be less than singles and plied yarns. Ishtiaque et al. (1993) studied the structure features of Siro-spun yarn and observed that the fiber packing density is not uniform across the yarn cross-section and it is not maximum at the core. The maximum packing density occurs at $1 / 3$ rd of the yarn radius from the yarn axis. Siro yarns are more compact near the yarn axis as compared to ring spun yarns. The total packing density of normal ring yarn is less than that of siro yarn. The cross-section of siro yarns show a close resemblance to that of single ring-spun yarn compared to conventional double yarn.

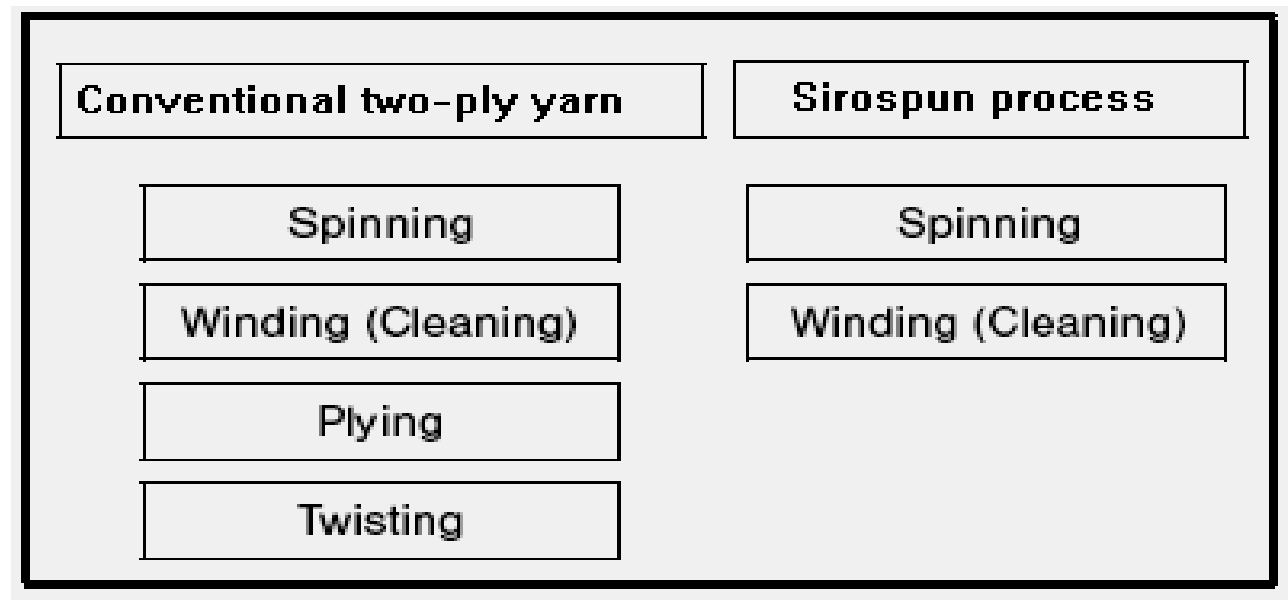

Figure 1. Workflow of conventional two-ply yarn and sirospun process 


\section{MATERIALS AND METHODS}

The Egyptian cotton Giza 88 variety of fiber characteristics: 35.5 UHM, 87.2 UI, 6.2 Elongation \%, $46.0 \mathrm{cN} /$ tex, 3.8 Micronaire value was used to produce cotton combing roving with $18 \%$ combing noils and 0.25 Ktex linear density in Al-Amria Spinning and Weaving Company, Alexandria. Sirospun and plied yarns of Ne 80/2 and $\mathrm{Ne} 50 / 2$ were produced as they are widely used for fine fabrics. Also, single yarns of $\mathrm{Ne} 40 / 1$ and $\mathrm{Ne}$ 25/1 yarn counts were spun by using the same roving. In Sirospun yarn production, Zinser's designed condenser was used before the middle drafting rollers to separate the double roving required for the production of yarns. The width of the centre parts of the condenser is $9 \mathrm{~mm}$ which is widely used in cotton spinning. Twist multiplier was kept at 4.3/tpi, for all yarn types and yarn counts.

For the plied yarn production, single yarns were firstly wound onto the cones, then were assembled by ROF doubling machine and finally twisted by WELLER ring twisting machine. During the twisting process, $8500 \mathrm{rpm}$ spindle speed was used for all the yarn counts. On the other hand, plied yarns are produced as a form of cones. Therefore, Sirospun yarns were also wound onto the cones and so all the comparisons were done in cone form.

The produced yarns were used as weft in $100 \%$ cotton fabric satin TC 300 $(80 / 2 * 80 / 2)$ and TC $300(50 / 2 * 50 / 2)$ on Sulzer PU weaving machine.

The yarn samples were tested in the Spinning Research Department, Cotton Research Institute, under standard conditions. Yarn count and twist, tensile strength, unevenness and hairiness were measured using the Zwiegle, Statimat ME and Uster Tester 3. The tensile strength properties of satin woven fabrics made from sirospun and two-fold yarns were investigated. During the processes, all the process parameters were kept constant for each sirospun and two-fold ring yarn type. The experimental results were statistically analyzed using the "Paired T-test" method.

The color reflectance and color strength (K/S between sirospun weft yarns and conventional Two-fold yarns were calculated using Perkin Elmer Spectrophotometer-Model Lambda 35 equipped with integrated sphere.

\section{RESULTS AND DISCUSSION}

The average test results of yarn count, twist, tensile strength, evenness and hairiness properties for both sirospun and twisted spun yarns were depicted in Table 1. The results are discussed in proceeding sections. 


\section{Tensile Properties}

Table 1 and Figures 2 and 3 show the tensile strength and elongation of sirospun and ring spun yarns for yarn counts. Statistical analyses show that at a $95 \%$ confidence limit the differences in the tensile property values were statistically significant in the two yarn types. sirospun yarns have statistically higher yarn tenacity and elongation than that of the plied and single yarns for all yarn counts. These results show that sirospun yarns are stronger and of higher elongation than plied and single yarns. However, unlike conventional two-fold yarn, both yarns are modified singles yarns with unidirectional twist. This is part of the reason why they have higher strength and elongation-at-break values. The fibers are in helical configuration in the double strand spun yarns, whereas the fibers in a conventional two-fold yarn are more aligned with the two-fold yarn axis, having most of their singles twist removed by the two-fold twist (Lamb and Wang 2010).
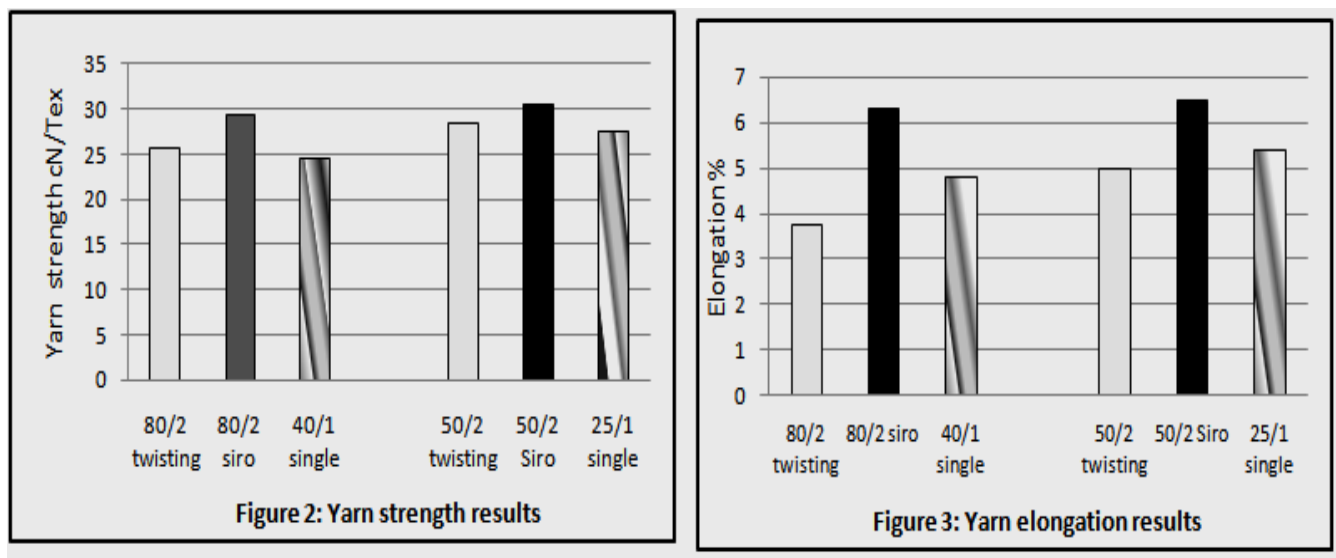

\section{Yarn evenness and imperfections}

When examined the yarn evenness of $100 \%$ cotton yarns, the Uster CVm\% of both siro and conventional two-fold yarns were found to have a statistically significant difference for a significance level of $a=0.05$ for both $80 / 2 \mathrm{Ne}$ and $50 / 2 \mathrm{Ne}$ yarn counts (Figure 4). The results indicate that two-fold yarns have slightly lower yarn evenness values than that of the twin slivers and single yarns for all yarn counts.

Total imperfections, as calculated by the sum of thin places, thick places and neps, were found to be very less of two-fold spun yarns, while high values were observed in the case of Sirospun yarns. 
Table 1 . Yarn quality properties

\begin{tabular}{|c|c|c|c|c|c|c|c|c|}
\hline & $\begin{array}{l}80 / 2 \\
\text { ring }\end{array}$ & $\begin{array}{l}80 / 2 \\
\text { siro }\end{array}$ & $\begin{array}{l}40 / 1 \\
\text { Single }\end{array}$ & $\begin{array}{c}\text { P. } \\
\text { Value }\end{array}$ & $\begin{array}{l}50 / 2 \\
\text { ring }\end{array}$ & $\begin{array}{c}50 / 2 \\
\text { siro }\end{array}$ & $\begin{array}{c}25 / 1 \\
\text { Single }\end{array}$ & $\begin{array}{c}\text { P. } \\
\text { Value }\end{array}$ \\
\hline Yarn count & 80.08 & 79.6 & 39.34 & - & 49.8 & 49.5 & 24.56 & - \\
\hline C.v. count $\%$ & 1.1 & 0.7 & 2.1 & - & 2.8 & 2.6 & 0.9 & - \\
\hline Twist factor & 4.3 & 4.3 & 4.3 & - & 4.3 & 4.3 & 4.3 & - \\
\hline $\mathrm{cN} / \mathrm{Tex}$ & 25.6 & 29.4 & 24.7 & 2.35 & 28.5 & 30.5 & 27.56 & 1.73 \\
\hline $\begin{array}{l}\text { C.v. } \\
\text { strength\% }\end{array}$ & 6.1 & 4.1 & 10.7 & 1.78 & 4.8 & 6.5 & 7.2 & 1.98 \\
\hline Elong. \% & 3.75 & 6.3 & 4.84 & 0.96 & 5 & 6.5 & 5.46 & 0.73 \\
\hline $\mathrm{CVm} \%$ & 11.8 & 11.8 & 11.4 & N.S & 10.5 & 10.9 & 10.6 & N.S \\
\hline Thin Places & 0 & 0 & 3 & - & 0 & 0 & 0 & - \\
\hline Thick Places & 13 & 23 & 20 & 3.67 & 13 & 30 & 8 & 4.54 \\
\hline Neps & 75 & 113 & 67 & 8.97 & 40 & 58 & 15 & 6.76 \\
\hline Hairiness & 4.9 & 3.4 & 4.3 & 0.76 & 6 & 4.4 & 5.6 & 1.34 \\
\hline
\end{tabular}
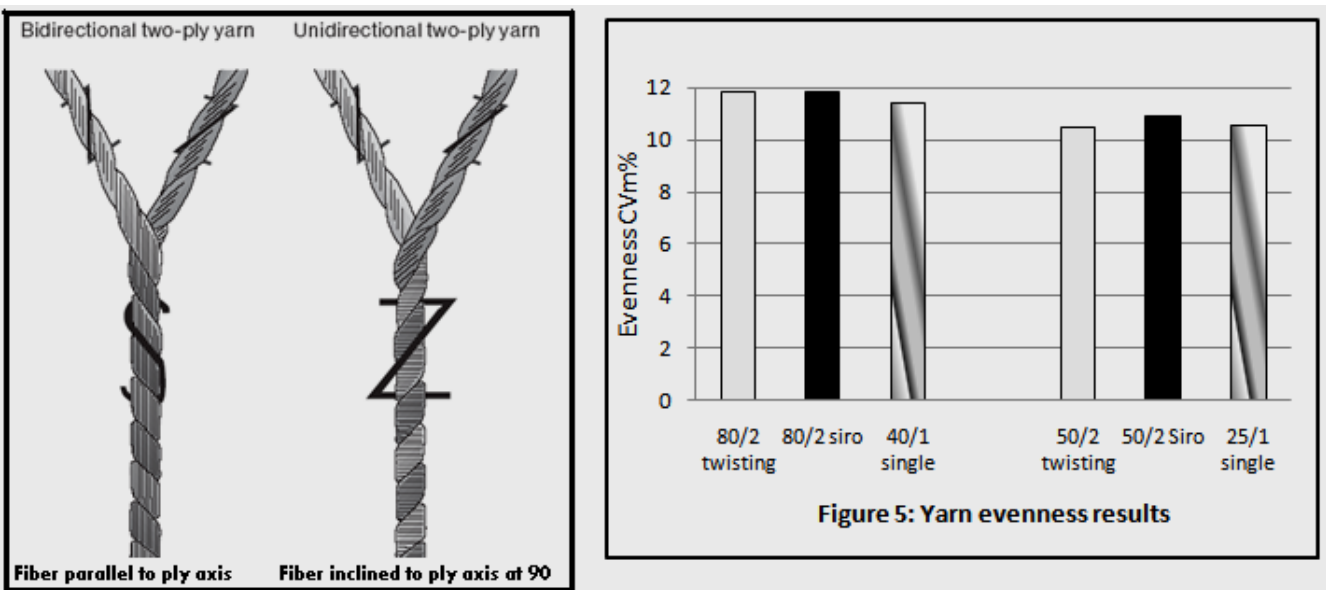

Figure 4: Conventional plied yarn with opposite direction of twist in the plied yarn (bidirectional twist), Siro yarn with identical direction of twist $\mathrm{i}$ in the plied yarn (unidirectional twist), Brunk (2006)

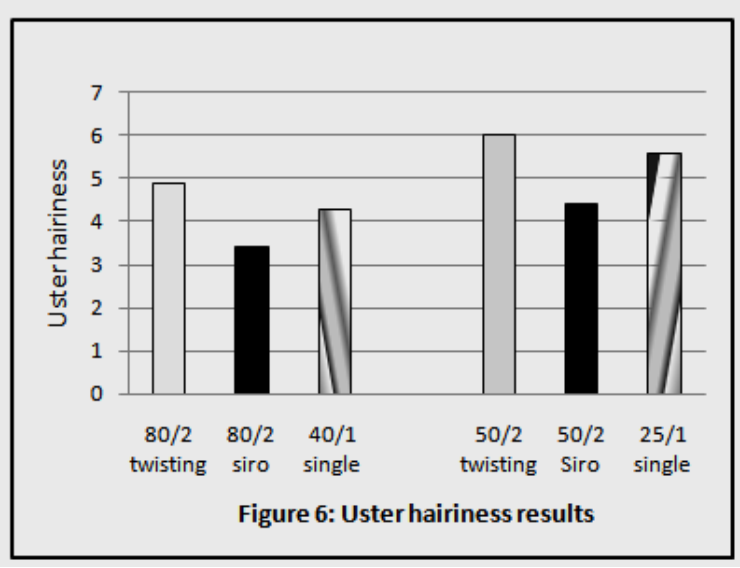




\section{Yarn hairiness}

Hairiness values measured in the yarn indicate the amount of short fibers and the variations in the fiber length, since the majority of the protruding hairs is contributed by the short fibers. According to Uster $\mathrm{H}$ values as presented in figure 5, lower hairiness values are observed in the case of sirospun yarn counts followed by single yarn counts and ring two-fold plied yarns. The difference between sirospun and other yarns are also statistically significant. Lower values of yarn hairiness observed in the case of sirospun could be, as stated in the tensile strength, due to unidirectional two-ply yarns.

\section{Fabric strength}

The results of the tensile strength experiments on woven fabrics are presented in Table 2 . The tensile strength values obtained in weft direction of the fabrics woven from sirospun yarns were higher than those obtained from fabrics woven from two-fold yarns. The differences between the tensile strength values of fabrics woven from sirospun and ring two-fold yarns changed similarly with the differences obtained between the yarns. Statistical differences were obtained between the fabrics woven from sirospun and ring two-fold yarns at the same comparison groups).

Table 2. Tensile strength and analysis of variance test results of the fabric

\begin{tabular}{|l|l|c|c|c|c|}
\hline \multirow{2}{*}{$\begin{array}{l}\text { Fabric } \\
\text { Group }\end{array}$} & & \multicolumn{3}{|c|}{ Weft direction } \\
\cline { 3 - 4 } & & $\begin{array}{l}\text { Breaking force } \\
(\mathrm{KgF})\end{array}$ & P Value & $\begin{array}{l}\text { Break elongation } \\
\%\end{array}$ & P Value \\
\hline 1 & $80 / 2 * 80 / 2$ Two-fold & 102.5 & \multirow{2}{*}{1.893} & 8.84 & \multirow{2}{*}{0.230} \\
\cline { 1 - 3 } 2 & $80 / 2 * 80 / 2$ SIRO & 106.5 & & 9.21 & \multirow{2}{*}{0.141} \\
\hline 3 & $50 / 2 * 50 / 2$ Two-fold & 80.33 & & 9.11 & \\
\hline 4 & $50 / 2 * 50 / 2$ SIRO & 83.40 & & 9.70 & \\
\hline
\end{tabular}

*Significant at $a=0.05$

Industrial importance: On account of certain commercial limitations in terms of maintaining two different spinning preparatory machines, processing of this novel product could help the Egyptian textile industries to develop products that reduce the cost of production.

\section{Color reflectance and strength $(K / S)$}

The test results of color reflectance of both sirospun and conventional twofold yarn are given in Table 3. The fabric samples were tested on a spectrophotometer under daylight conditions. 
The dyed fabric samples consisting of sirospun yarns indicated that there is insignificant differences in color reflectance between the fabrics of sirospun and conventional two-fold fabric in $80 / 2$ and 50/2, although they were weaved and dyed under identical conditions. The sirospun fabrics recorded slightly higher reflectance than the conventional two-fold fabrics.

When comparing how the color strength (K/S) of the fabrics change, the findings indicate no significant difference between the fabrics of sirospun and conventional yarns. The sirospun fabrics recorded slightly lower color strength than the conventional two-fold fabrics. This result reveal that much less dye can be used for the fabrics of sirospun fabric, so their dyeing cost might be lower for the same depth of shade, in comparison to the fabrics of conventional two-fold yarns.

Table 3. The change in the color reflectance and shade of the fabrics

\begin{tabular}{|c|c|c|c|c|c|}
\hline Fabric & & \multicolumn{4}{|c|}{ Weft direction } \\
\hline Group & & $\mathrm{R} \%$ & P. value & $\mathrm{K} / \mathrm{S}$ & P. value \\
\hline 1 & $80 / 2 * 80 / 2$ Two-fold & 17.6 & \multirow{2}{*}{ N.S } & 2.0 & \multirow{2}{*}{ N.S } \\
\hline 2 & $80 / 2 * 80 / 2$ SIRO & 18.2 & & 1.9 & \\
\hline 3 & $50 / 2 * 50 / 2$ Two-fold & 18.4 & \multirow{2}{*}{ N.S } & 1.8 & \multirow{2}{*}{ N.S } \\
\hline 4 & $50 / 2 * 50 / 2$ SIRO & 19.2 & & 1.7 & \\
\hline
\end{tabular}

*N.S.: Not significant 


\section{REFERENCES}

1. Anonymous. Melliand International, vol 79, no 10, 1993, p 238.

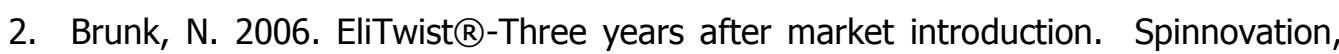
22 (July): 10-16.

3. Cheng, K. P. S. and M. N. Sun. 1993. Structure and Properties of Cotton Sirospun Yarn.' Textile Research Journal, vol 68, no 7, July 1998, p 520.

4. Ishtiaque S. M., I. C. Sharma and S. Sharma. 1993. Structural mechanics of siroyarn by microtomy.' Indian Journal of Fibre and Textile Research, vol 18, no 3, 1993, p 116.

5. Lamb P. R. and X. Wang. 2010. Advances in yarn spinning technology, ch. 8 Pp: 217-236. Woodhead Publishing series in textiles: No. 9.

6. Saravananm D. and S. Kumar. 2009. A novel approach to process cotton/long staple fibre blends on short staple ring frame. Indian Journal of Fiber \& Textile Research, Vol. 34, March 2009,pp47-51.

7. Sun, M. N. and K. P. S. Cheng. 2000. Structure and Properties of Cotton Siro-spun Yarn. Textile Research Journal, vol 70, no 3, 2000, p 261.

8. Yilmaz, D. and S. Ibrahim. 2010. Analysis of Sirospun, plied and single yarns properties. Beltwide Cotton Conferences, New Orleans, Louisiana, January 4-7, 2010. $1647-1654$ 


\title{
مميزات الأقمشة القطنية المصنوعة من خيوط السيرو و المزوية
}

\author{
محمد عبد الرحمن محمد السيا سوزان حسينى سنا \\ معز بحوث القطن - مركز البحوث الزراعية - الجيزة
}

تتميز خيوط السيرو بإختصار مرحلتين فى انتاجها بالمقارنة بالخيوط المزوية وبالتبعية

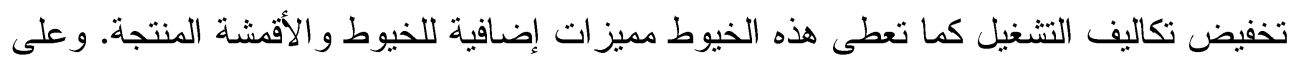

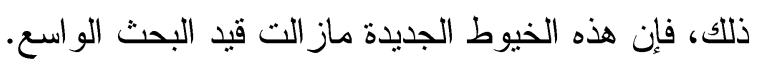

الهدف من هذه الدراسة هو عرض وتحليل قياسات الجودة للخيوط و الأقشة المنتجة من

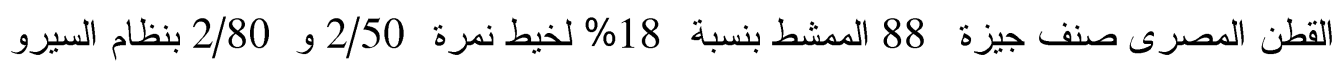
ونظام الزوى التقليدى. بالإضافة إلى انتاج خيوط نمرة 1/40 و 1/25 للمقارنة وتحليل خو اص

جودتها.

تم قياس الخو اص الفيزيائية للخيوط متضمنة متانة الخيط المفرد، الاستطالة، الانتظام

و التشعير ومقارنتها. و قد أظهرت قيم خو اص جودة خيوط السيرو مستويات افضل فى المتانة و الاسنطالة و التشعبر، حيث اظهرت الخيوط نمرة 2/50 و 2/80 انخفاض معنوى لقيم المتانة

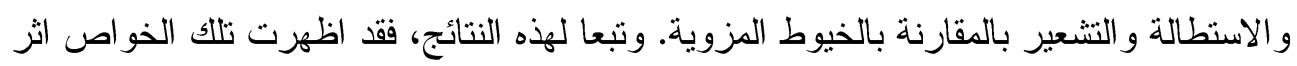
معنويا على متانة واستطالة الأقمشة فى إتجاه اللحمة فى الخيوط المغزولة على بلى نظام السيرو عنها فئى الخيوط المزوية.

أظهرت قياسات انعكاس وقوة اللون فروقا غير معنوية بين الأقمشة المنسوجة فى اتجاه

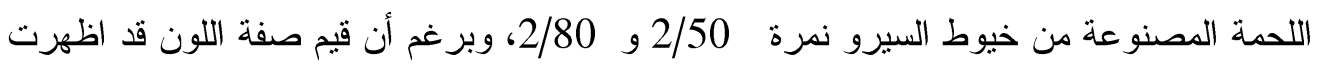

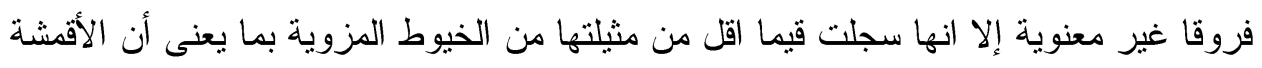
المنسوجة من خيوط السيرو تسنهلك صبغة أقل وبالتالى، ربما تخفض منالئ مناليف الانتاج بالمقارنة بالخيوط المزوية المنسوجة بالطريقة التقليدية. 